papers were prepared by members of the Canadian delegation; C.R. Silversides, Forest Management Institute, Canadian Forestry Service discussed "The development of simple tools for forestry work" while J.W. Andresen, Faculty of Forestry and Landscape Architecture, University of Toronto, discussed "Urban forestry and its influences in human settlements". In all some 530 addresses and papers were prepared for the Congress; of these about 20 were submitted by $\mathrm{Ca}$ nadians. The proceedings of the Congress will be published.

In addition to the general and technical sessions, a number of "satellite" meetings were held. These included IUFRO meetings on panel products, torrents, snow and avalanches, a special meeting on bamboo research, and a Man and Biosphere/IUFRO workshop on tropical rain forest ecosystems, plus a meeting for each discussion area in which authors of invited and special papers were able to highlight or summarize their papers.

A Congress Declaration was issued, following the practise initiated at the VIIth World Forestry Congress held in Buenos Aires, Argentina. In the declaration it was noted that the world's forests must be maintained on a sustainable basis, for the use and enjoyment of all people. The forest is a resource that is under increasing pressure from billions of people, but it was recognized that the world's forests were still vast in extent, that they represent a renewable resource, that their biomass is by far the largest of all vegetation types and that the potential for sustained growth and production and for expansion is still immense. The Congress paid particular attention to the role which forests can play in improving conditions for agricultural and livestock production as well as providing a source of supplementary animal fodder in dry periods. In many countries, forests provide for the direct production of food from forests and forest trees and from wild fauna. It was also noted that forestry must make its full contribution to the development of rural communities, particularly of the rural poor of the developing world. The declaration also noted the many implications of the energy crisis for forestry and forest industries. The Congress was particularly concerned with the "poor man's energy crisis" the growing firewood shortage brought about by population pressures, diminishing forests and the increased cost of alternative means of cooking and heating. It was noted that 1500 million of the rural poor depend on fuelwood for cooking and heating. The possibility for forests to become an important source of high grade as well as low grade energy was noted. Some other points noted in the declaration include serious losses of tropical forests, the need to improve conditions of work of forest workers, the need to offer equal employment opportunities for both men and women and the need to preserve representative areas of all major forests as gene pools, scientific benchmarks and as habitats for wildlife and as examples of man's cultural heritage. Also emphasized was the point that a sound scientific and technical foundation is required to the wise use of all forest resources. And finally - of significance as far as Canada is concerned - the declaration urged that all governments proclaim an official forestry policy.

The Congress was held in the air-conditioned Jakarta Convention Hall which was excellently equipped for the purpose. The Convention Hall also was the locale for a forestry exhibit which featured a number of industrial exhibits plus exhibits by the governments of Canada, Sweden, Indonesia and British Columbia. A brochure entitled "Forests for People" was published by the Canadian Forestry Service in the English, French, Spanish and Indonesian languages. In addition, forestry films were shown on several nights; several Canadian films were projected. A tree planting ceremony was also held at the Jakarta Forestry Centre; a native tree species was planted by a representative of each country and international organization. Social events were not neglected by the Indonesian government; on the first night there was an opening reception; during the Congress there were two cultural shows, and there was a farewell buffet dinner at the conclusion of the Congress. Special stamps and a coin were issued to commemorate the Congress.

Three study tours were conducted in Indonesia, each both before and after the Congress. The main study tour was to East Kalimantan (formerly Borneo), Bali, and East and Central Java. Other study tours were held in North Sumatra and in Central Java. In addition, study tours were organized by a number of adjacent countries.

The Congress and the study tours were well organized and the Indonesians were friendly, hospitable and helpful. A brochure issued by the $\mathrm{Di}$ rectorate General of Tourism states that "the primary characteristic of the Indonesian people regardless of location or religion, is their generous hospitality. A lovely smile, a gracious welcome..." and I am sure that all those who visited Indonesia to attend the Congress will attest to the accuracy of the above statements.

J.H. Cayford

\section{Third Eastern Spruce Budworm Research Work Conference}

17 - 19 January 1979. University of Maine, School of Forest Resources, Orono.
Contact: Dr: John Dimond, 313 Deering Hall

University of Maine, Orono, Maine 04473 (phone 207-581-7704)

for program and accommodation information. 